\title{
Cristãos-novos, marranos e judeus no espelho da Inquisição*
}

\author{
Robert Rowland
}

Qualquer discussão sobre o papel desempenhado pelos judeus na construção do Novo Mundo ${ }^{1}$ passa pelo esclarecimento de uma espinhosa questão prévia: a dos critérios segundo os quais, e em que sentido, determinado indivíduo poderá ser considerado como judeu. Quer no caso dos judeus da Europa central e oriental, quer no daqueles judeus de origem ibérica que, antes de abandonarem a Europa, ou após a sua chegada à América, pertenciam a uma comunidade judaica (fosse ela oficialmente reconhecida ou apenas tacitamente tolerada), a resposta é bastante evidente. Mas o caso dos "cristãos-novos" espanhóis e portugueses é diferente.

Oficialmente, já não havia judeus na Espanha ou Portugal, ou nos respectivos impérios, desde finais do século XV, quando apenas foram autorizados a permanecer os que tivessem se convertido - voluntariamente ou não - ao catolicismo, bem como os seus descendentes católicos. Visto serem todos nominalmente católicos, estavam sob a jurisdição da Inquisição, sujeitos a procedimento penal se fossem acusados de quaisquer atos ou palavras que pudessem levantar suspeitas quanto à sinceridade de sua fé católica.

No mundo ibérico dos séculos XVI, XVII e XVIII, por conseguinte, todos os judeus remanescentes eram necessariamente judeus clandestinos, para quem era de importância vital dissimular suas práticas e seus sentimentos religiosos. Aquilo que sabemos a seu respeito resume-se assim, quase exclusivamente, à informação produzida pela Inquisição através de seus esforços para erradicar os últimos vestígios de judaísmo ibérico. As pesquisas genealógicas efetuadas a respeito dos candidatos a determinados cargos ou à admissão às ordens militares possuíam o mesmo quadro de referência antijudaico. Na realidade, quase não existem testemunhos independentes a respeito da sobrevivência do judaísmo na Península, sendo dominante a documentação produzida pela Inquisição ou à sua sombra.

Quer na Espanha, quer em Portugal, é evidente que nem todos os descendentes dos que se converteram, ou foram convertidos, no século XV se mantiveram fiéis ao judaísmo, e que o fato de um indivíduo ser de ascendência inteira ou parcialmente judaica não significava, por si só, que ele se considerasse, ou fosse considerado por outros, judeu. ${ }^{3}$ É verdade que os descendentes dos judeus convertidos estavam sujeitos a diferentes formas de discriminação por causa da sua "impureza de sangue", sendo intrinsecamente suspeitos em matéria de fé; mas isto não justifica a presunção, por parte dos historiadores, de que tais preconceitos e suspeitas tivessem qualquer base factual. Com efeito, muitos cristãos-novos, cujas famílias tinham desde há muito perdido qualquer contato com a tradição judaica, viram-se falsamente acusados, por inimigos ou rivais, da prática secreta de ritos e cerimônias judaicas, aparecendo como "judaizantes" nos registros da Inquisição.

Como não deixaram de notar vários autores da época (cf. BETHENCOURT, 1994, p. 295-339), os procedimentos da Inquisição eram tais que um cristão-novo falsamente acusado de reversão ao judaísmo dificilmente conseguiria provar sua inocência. De resto, a tentativa de fazê-lo era tão arriscada que muitos preferiam oferecer aos inquisidores uma confissão falsa, incluindo uma lista imaginária dos seus cúmplices. Podiam, assim, ter alguma esperança de se livrarem do cárcere apenas com o confisco dos seus bens e outras penas relativamente menores, em vez de serem condenados à morte como negativos. Em tais circunstâncias, nem as confissōes relativas às próprias crenças ou práticas judaicas, nem as informaçôes fornecidas a respeito de outros cristãos-novos poderão, a priori, ser consideradas fidedignas.

\footnotetext{
${ }^{*}$ Este artigo reproduz, com algumas alteraçōes, um texto publicado sob o título de "Être juif au Portugal au temps de l'Inquisition: nouveaux chrétiens, marranes, juifs", Ethnologie française, XXIX/2, 1999, p. 191-203, e de "New Christian, Marrano, Jew”, em Bernardini e Fiering, 2001, p. 125-148. Tradução do autor.
} 
O retrato do judaísmo dos cristãos-novos ibéricos que nos oferecem os registros da Inquisição não pode, por conseguinte, ser aceito tal e qual. Sem dúvida, muitos cristãos-novos conseguiram manter, na clandestinidade, algum tipo de prática religiosa judaica. Mas nem todos se mantiveram secretamente fiéis ao judaísmo, e a suspeição generalizada de que os cristãos-novos eram objeto, por causa das suas origens, era frequentemente destituída de fundamento. Podemos ter a certeza que nem todas as confissões de práticas judaicas próprias ou acusações de cumplicidade feitas contra terceiros durante os interrogatórios tinham uma base factual. Como veremos adiante, não há dúvida de que, em alguns casos, a observância de algumas práticas religiosas judaicas se terá mantido até o século XVIII. Mas, em termos gerais, não dispomos de critérios claros e objetivos que permitam determinar quais as confissões e acusações que eram verdadeiras e quais as que eram, pelo contrário, apenas o resultado dos procedimentos inquisitoriais e do preconceito generalizado antijudaico. ${ }^{4}$ A natureza das nossas fontes é tal que, se não tivermos um cuidado extremo, estas apenas irão confirmar os nossos pressupostos, demonstrando, conforme os casos, quer que a maioria dos cristãos-novos acusados perante a Inquisição se tratava, na realidade, de criptojudeus empenhados na manutenção de tradições ancestrais, quer, pelo contrário, que eram vítimas inocentes do preconceito antijudaico, de acusações falsas e da perversidade dos procedimentos da Inquisição.

Em certo sentido, trata-se de uma situação análoga à de um historiador confrontado com os processos de pessoas acusadas de feitiçaria na Europa dos séculos XVI e XVII e com as confissões estranhamente repetitivas que aqueles contêm. Alguns autores aceitaram a veracidade das acusações e confissóes: para eles, como para os demonólogos da época, a natureza estandardizada das confissões é apenas uma prova da força e influência do "inumerável exército de Satanás". A maioria dos historiadores, no entanto, está convencida, desde há muito, de que os fenômenos de feitiçaria não tinham existência real e de que muitas das ações descritas nas confissões eram, na realidade, impossíveis. A sua descrença, ou pelo menos ceticismo, leva-os a procurar, na natureza da repressão dirigida contra os suspeitos de feitiçaria, uma explicação externa para o caráter estereotipado das confissões. De acordo com esta interpretação, os acusados estariam respondendo, sob tortura ou ameaça de tortura, às mesmas perguntas insidiosas feitas por magistrados e inquisidores que tinham lido os mesmos tratados sobre feitiçaria. A representação estandardizada desta e o papel, nessa representação, do sabá das bruxas, poderia assim ser atribuída à forma como a repressão da feitiçaria era organizada pelos tribunais seculares e eclesiásticos. Num caso como no outro, são as convicções prévias dos autores a respeito da realidade da feitiçaria que determinam a interpretação das fontes e a própria definição daquilo que carece de explicação (ROWLAND, 1990).

Em relação aos cristãos-novos, de igual modo, os mesmos registros judiciais podem ser lidos de maneira completamente diferente, consoante as concepções prévias de cada historiador. Alguns verão, na lista esquemática de "práticas judaicas" estereotipadas que encontramos na maioria das confissões, uma tentativa de manutenção de tradições ancestrais em condições adversas, com poucas possibilidades de troca de informações com outros judeus clandestinos e, menos ainda, de estabelecimento de contatos com comunidades judaicas no estrangeiro. Outros interpretarão essas mesmas características como evidenciando um processo de categorização (labelling) pelo qual atributos estereotipados, projetados sobre uma minoria a partir do exterior, são posteriormente confirmados através de supostas "confissões" obtidas pelos interrogatórios e pela tortura, e recusar-se-ão, por isso, a aceitá-las, sem mais, como testemunhos da persistência do judaísmo na Espanha e Portugal na época moderna.

Tal como no caso das crenças e práticas atribuídas às feiticeiras na Europa no mesmo período, não é possível responder diretamente à questão da base factual das acusações de "judaísmo" dirigidas contra os cristãos-novos. E, tal como nos processos de feitiçaria europeus, o esclarecimento da questão (que, de qualquer modo, terá de ser indireto) passa por um exame contextual mais aprofundado da situação dos cristãos-novos na sociedade ibérica ao longo do tempo, do papel da Inquisição em diferentes lugares e épocas e, por fim, das circunstâncias específicas de cada acusação individual. 
A este respeito, a primeira questão que deve ser considerada, mesmo que possa parecer demasiado óbvia para merecer atenção, é a do estatuto jurídico dos judeus relativamente à Inquisição. A dramática expulsão e conversão forçada dos judeus espanhóis e portugueses e a posterior repressão do "judaísmo" pelas inquisiçóes ibéricas tenderam a obscurecer o fato de aqueles, em princípio, não estarem sequer sob jurisdição inquisitorial. Na verdade, como foi reiterado, em particular, na bula Antiqua iudaeorum improbitas, do papa Gregório XIII (1581), judeus, muçulmanos e outros não cristãos não estavam normalmente sujeitos à Inquisição. Em si, as crenças e práticas religiosas dos não cristãos autorizados a residir em determinado território não lhe diziam respeito, desde que permanecessem circunscritas à esfera doméstica ou às zonas próprias de residência (EYMERICUS, 1578, p. 288 sq.; CARENA, 1655, p. 251-5; [MASINI], 1625, p. 19-20; STOW, 1994). Em certas situações, contudo, e em particular quando se desconfiava que a natureza dos seus contatos com membros da população cristã poderia colocar em risco a fé destes últimos, a Inquisição tinha o dever de intervir. Tal seria o caso, por exemplo, se houvesse judeus que tentassem (ou que tivessem sido acusados de tentar) convencer conversos a regressarem às crenças ancestrais. De fato, e oficialmente, foi para deter a influência que eram acusados de exercer sobre os numerosos judeus convertidos ao catolicismo durante o século XV que os judeus espanhóis restantes, não convertidos, foram expulsos em 1492.

A situação dos judeus convertidos e dos seus descendentes era completamente distinta da daqueles que permaneceram na antiga fé. Todos os que tivessem sido batizados como católicos encontravamse sob a jurisdição da Inquisição. Durante o século XV, na Espanha (e, em menor medida, em Portugal também), muitos cristãos-novos eram suspeitos de continuarem a praticar secretamente o judaísmo, sendo acusados de terem feito uma conversão fingida e oportunista para conseguirem ter acesso a cargos que eram vedados aos judeus. As mesmas acusações eram dirigidas contra os descendentes desses conversos que, apesar de terem sido batizados como católicos, eram suspeitos de terem sido educados em segredo como judeus, de se manterem fiéis à "Lei de Moisés" e de praticarem ritos e cerimônias judaicas. Em termos formais, tais comportamentos da parte de um católico batizado eram considerados apostasia e podiam, como tal, ser punidos como heresia pela Inquisição. Foi, precisamente, a necessidade de perseguir e extirpar tal heresia entre os cristãos-novos que serviu de justificação para a introdução da Inquisição em Castela em finais do século XV. A criação da Inquisição portuguesa em 1536 foi justificada com argumentos análogos.

Neste sentido, todas as relações entre a Inquisição e os judeus - quer se tratassem daqueles que viviam abertamente como tais (onde isto continuou a ser permitido, como em muitas regiões de Itália), quer daqueles que mantinham clandestinamente, como na Península Ibérica, uma identidade e prática religiosa judaicas - refletiam, e tinham como base, as relaçóes entre judeus e católicos: no primeiro caso, e consoante a região, entre as comunidades judaica e católica (que englobava os cristãos-novos); no segundo, entre a identidade pública de cristão-novo católico de cada indivíduo e a sua identidade secreta, ou familiar, de judeu clandestino. Por conseguinte, a informação que nos é fornecida pelas fontes inquisitoriais diz respeito ou às relações entre as comunidades judaicas e católicas, ou então à relação entre as identidades judaica e católica de determinados indivíduos. Em nenhum dos casos essa informação diz respeito exclusivamente às crenças e identidades de judeus enquanto tais.

De resto, o fato das relações entre cristãos-novos e Inquisição derivarem essencialmente da sua dupla identidade (real ou imaginada) de católicos e judeus não se espelha apenas nos conteúdos das fontes inquisitoriais. A presença e atividade da Inquisição reforçou essa dualidade, fazendo lembrar a todos os cristãos-novos - incluindo aqueles cuja conversão ao catolicismo fora sincera, bem como os seus descendentes - que podiam, a qualquer momento, ser suspeitos e acusados de se manterem clandestinamente fiéis ao judaísmo. Ao mesmo tempo, todos aqueles que pretendiam e conseguiam, de alguma 
forma, conservar uma identidade judaica eram obrigados a praticar uma dissimulação constante. De uma forma ou de outra, todos os cristãos-novos ibéricos eram judeo-católicos.

É preciso não esquecer, contudo, que as Inquisições de Espanha, Portugal e Itália não se ocupavam apenas das crenças e práticas religiosas dos judeus convertidos e dos seus descendentes. No que diz respeito à população católica sob a sua jurisdição, interessava-lhes o conjunto de comportamentos que, de alguma maneira, pudessem ser considerados heréticos. Um segundo aspecto que deve, assim, ser levado em conta, ao analisarmos as relações da Inquisição com os cristãos-novos de origem judaica, é o lugar ocupado pelas acusações de judaísmo no conjunto da atividade repressiva destes tribunais.

$\mathrm{Na}$ historiografia tradicional, a Inquisição tem sido normalmente considerada do ponto de vista da sua ação de prevenção e repressão da dissidência religiosa. Tal caracterização, que reproduz a definição que a própria dava do seu papel e função, vincula o estudo da Inquisição à história das ideias e concentra as atenções sobre as suas vítimas, sobre um número relativamente restrito de processos célebres e sobre a luta contra a censura e pela liberdade de expressão e de religião.

Durante as últimas décadas, no entanto, tem vindo a afirmar-se uma outra abordagem, baseada numa análise estatística da atividade dos diferentes tribunais. Em 1978, numa comunicação pioneira apresentada em um colóquio sobre a Inquisição espanhola realizado em Copenhague, Gustav Henningsen e Jaime Contreras chamavam a atenção para o fato de menos da metade das pessoas processadas pelos tribunais da Inquisição espanhola, entre 1560 e 1700, terem sido acusadas de heresia formal (incluindo o judaísmo, o maometismo e o luteranismo); a maioria dos processos, com efeito, dizia respeito a delitos menores, tais como a bigamia, a blasfêmia e formas diversas de superstição (CONTRERAS e HENNINGSEN, 1986). De resto, entre os tribunais havia diferenças consideráveis. Estes números puseram em questão alguns dos pressupostos subjacentes às abordagens mais tradicionais e incentivaram outros pesquisadores a empreender o mesmo tipo de análise em relação às Inquisições romana e portuguesa.

Os resultados não se fizeram esperar ${ }^{5}$ e tornaram evidente que a atividade da Inquisição não podia ser reduzida a um único modelo. No Norte da Itália, por exemplo, a repressão foi, numa primeira fase, dirigida principalmente contra a influência da Reforma: os acusados de protestantismo representavam 68\% dos processados em Veneza entre 1547 e 1585, e 53\% dos processados no Friuli entre 1557 e 1597. Em Nápoles, por outro lado, os principais delitos entre 1564 e 1590 eram a feitiçaria e a magia ilícita (24\%), enquanto que os acusados de "luteranismo" constituíam apenas 3\% do total. A partir do século XVII, também no Norte da Itália as artes mágicas já tinham se tornado a preocupação principal da Inquisição.

$\mathrm{Na}$ Espanha, a situação era completamente distinta, com variações significativas entre tribunais. Apesar da informação de que dispomos sobre a primeira vaga de terror ser muito incompleta, não há dúvida de que as vítimas da Inquisição, entre 1480 e 1530, eram quase todas cristãos-novos acusados de terem se mantido secretamente fiéis ao judaísmo. De acordo com a estimativa feita por Dedieu para Toledo (1989, p. 240), houve durante este período 3.196 processos e 283 execuçōes: $87 \%$ tiveram a sua origem em acusações de judaísmo.

Em relação ao período seguinte, a nossa informação é mais completa, e o quadro é radicalmente diferente. Entre 1540 e 1700, em dezenove tribunais da Inquisição espanhola, 24\% dos processos foram por maometismo, $10 \%$ por judaísmo, e $8 \%$ por protestantismo. Os restantes, como já se referiu, diziam respeito a delitos menores. As acusaçôes de maometismo deram origem a $29 \%$ dos processos em Aragão e a $18 \%$ em Castela. Inversamente, as de judaísmo correspondiam a $18 \%$ dos processos castelhanos, mas só a $4 \%$ dos aragoneses. ${ }^{6}$

Tal como na Itália, o modelo de repressão se modificou ao longo do tempo. Durante o primeiro período, o judaísmo era, em quase todos os tribunais então existentes, a preocupação principal. Na segunda metade do século XVI, continuou-se a repressão contra os moriscos de Aragão e Granada, mas os 
tribunais restantes começaram a preocupar-se com os delitos relativamente menores dos cristãos-velhos (católicos de origem não conversa) e com o que se denominou de "administração da fé" (DEDIEU, 1989). Os casos de luteranismo continuaram a ser relativamente raros. Ao longo do século XVII, e até o período de decadência da Inquisição, as acusações de judaísmo tornaram-se novamente mais frequentes; mas desta vez as vítimas eram, na sua maioria, cristãos-novos de origem portuguesa que tinham se transferido para a Espanha e para o império espanhol, por motivos econômicos ou para fugir à maior severidade da Inquisição portuguesa.

Esta, de fato, constituía uma exceção no contexto das três Inquisições modernas. Após a sua criação relativamente tardia em 1536, não houve uma vaga de terror inicial, como na Espanha, e a intensidade da repressão manteve-se relativamente constante entre meados do século XVI e finais do XVII, seguindo-se um declínio gradual ao longo do XVIII. Mas, mesmo durante os anos 1675 a 1767, antes das reformas pombalinas, os três tribunais portugueses completavam ainda, em média, 59 processos por ano. No conjunto do período entre 1536 e aquelas reformas - que, entre outras medidas, aboliram a distinção entre cristãos-novos e cristãos-velhos -, a Inquisição portuguesa preocupou-se quase exclusivamente com a erradicação de crenças e práticas judaicas entre os primeiros. No tribunal de Lisboa, cuja jurisdição se estendia ao Brasil e à África Ocidental, as acusaçōes de judaísmo estiveram na origem de 68\% de todos os processos entre 1540 e 1629 . No tribunal de Coimbra, correspondiam a $83 \%$ dos processos entre 1566 e 1762, e em Évora, entre 1553 e 1688, a proporção era de 84\%.

O contraste com os tribunais italianos, e mesmo com os da vizinha Castela, é mais do que evidente. Visto que a atividade de todas as Inquisições modernas era regulada por um único quadro doutrinal e institucional, as diferenças entre Inquisições e, no interior de cada uma delas, entre tribunais requerem uma explicação contextual, em função do tempo e do lugar. Nestes termos, a singular concentração da atividade dos tribunais portugueses, ao longo da sua existência, no delito de judaísmo só se tornará explicável à luz da situação específica dos cristãos-novos na sociedade portuguesa e da sua evolução entre finais do século XV e meados do XVIII.

\section{IV}

$\mathrm{Na}$ raiz desta especificidade, está a história contrastada dos judeus espanhóis e portugueses durante o século XV. Na Espanha, os massacres de 1391 e o clima de hostilidade continuada contra os judeus que se lhe seguiu tinham dado origem a uma vaga de conversões ao catolicismo. Muitos conversos vieram, posteriormente, ocupar cargos que, anteriormente à sua conversão, lhes tinham estado vedados, sendo frequentemente suspeitos de terem fingido aderir à fé católica justamente para poderem ter acesso a tais posições. Acusações deste tipo vieram aumentar tensões já existentes relacionadas com o papel desempenhado por muitos conversos na economia urbana, as quais, muitas vezes, degeneravam em episódios de violência. Em um outro nível, como em Toledo em 1449, houve tentativas de instituir, com base na noção de "limpeza de sangue", novas formas de exclusão de conversos e seus descendentes. A situação em muitas zonas de Castela em 1475, no início do reinado de Fernando e Isabel e pouco antes do estabelecimento da Inquisição, podia ser descrita como sendo de guerra civil latente ou mesmo aberta (DOMÍNGUEZ ORTIZ, 1988, p. 26).

Em Portugal, o quadro era, de novo, completamente diferente. É verdade que, tal como na Espanha, a minoria judaica constituía, relativamente ao resto da Europa, uma fração muito significativa da população. Em finais do século XV, haveria talvez trinta ou quarenta mil judeus, ou seja, 3\% a 4\% da população. A grande maioria era composta por artesãos e comerciantes, pelo que é legítimo considerar que os judeus representariam uma proporção muito mais elevada nas vilas e cidades, ultrapassando os $10 \%$ em muitas localidades. ${ }^{7}$ Mas estavam, efetivamente, sob a proteção do Rei. Em 1392, numa altura em que muitos judeus espanhóis eram massacrados ou obrigados a converter-se, a legislação portuguesa de proteção aos judeus era confirmada. ${ }^{8}$ Foi só na segunda metade do século XV, com a chegada de ca- 
da vez mais judeus e conversos refugiados de Espanha, que começaram a aparecer sinais de intolerância. Mas, em geral, estes imigrantes foram facilmente integrados, consoante os casos, nas populaçôes judia ou católica. Ao contrário do reino vizinho, em Portugal não havia qualquer "problema converso".

À medida que as tensões na Espanha se agravavam, e sobretudo depois do estabelecimento da Inquisição, houve um aumento dramático do afluxo de judeus e conversos espanhóis a Portugal, o que provocou reações no seio das populações do Porto e de Lisboa. Em 1488, D. João II proibiu a entrada em Portugal de mais conversos castelhanos e, ao mesmo tempo, incentivou os que aí se tinham refugiado a emigrarem, sobretudo para o Norte de Europa (TAVARES, 1987, cap. 1). Apesar disso, após a sua expulsão da Espanha em 1492, o mesmo monarca permitiu que os judeus espanhóis se instalassem em Portugal. Fontes e historiadores divergem quanto ao número exato daqueles que procuraram refúgio no reino, ${ }^{9}$ mas é provável que a sua chegada tenha feito duplicar o número de judeus existentes no território, que passaram a representar cerca de 6 a $8 \%$ da população.

Não será preciso repetir aqui a conhecida história, relatada de maneiras diferentes, mas igualmente dramáticas, pelo humanista Damião de Góis (1566-7) e pelo judeu exilado Samuel Usque (1553), de como os Reis Católicos Fernando e Isabel impuseram como condição para o casamento de sua filha com o novo rei D. Manuel que os judeus fossem também expulsos de Portugal, e de como o Rei, tendo primeiro decretado em 1497 a expulsão de todos os judeus portugueses e espanhóis que não aceitassem converter-se, em seguida fez tudo para impedir a sua partida, sujeitando-os, finalmente, a um batismo forçado e coletivo.

Fossem quais fossem as motivações da Coroa portuguesa - sendo provável que tenham sido, pelo menos em parte, de natureza econômica - não há qualquer dúvida quanto à política adotada em relação aos judeus recém-convertidos, os quais foram encorajados a integrar-se completamente na sociedade portuguesa. Mesmo antes da data limite fixada para a expulsão, o Rei determinou, numa tentativa de dissipar o receio de que, tal como na Espanha, os conversos pudessem vir a ser objeto de perseguição inquisitorial, que quem aceitasse converter-se não seria sujeito, durante um período de vinte anos, a qualquer tipo de investigação sobre as suas crenças e práticas religiosas. Além disso, todas as formas de discriminação socioeconômica contra os cristãos-novos - exceto, num primeiro momento, a proibição de abandonarem o Reino - foram abolidas. Havia a presunção - ou, talvez, a esperança - de que a igualdade de tratamento os levaria, com o tempo, a tornarem-se bons católicos. O mesmo pressuposto parece ter estado subjacente à espantosa lei de 1498, a qual proibia os casamentos entre cristãos-novos: pensava-se, segundo parece, que os frutos de um casamento misto seriam, com maior probabilidade, educados como católicos (TAVARES, 1987, p. 41-51).

Em 1507, dez anos após a conversão forçada, a proibição de abandonar o Reino foi levantada, e reiterou-se a promessa de não submeter os cristãos-novos a qualquer investigação em matéria de fé. Cinco anos mais tarde, o compromisso foi renovado por outros dezesseis anos. Alguns autores judeus referiam-se a D. Manuel como "o Rei pio", e em certas famílias cristãs-novas chamava-se-lhe mesmo "El-rei judeu" (KAYSERLING, 1971, p. 154). Em termos gerais, esta política parece ter sido relativamente bem-sucedida, e com a exceção evidente do massacre de Lisboa de 1506, que foi severamente punido pelo Rei, ${ }^{10}$ houve poucos indícios, nas primeiras décadas do século XVI, das tensões abertas e da violência que tinham marcado a sociedade espanhola durante o século anterior e preparado o terreno para a introdução da Inquisição.

E, no entanto, a integração foi apenas parcial. Provocadas em parte por rivalidades de natureza econômica, persistiram tensões latentes entre setores da população cristã-velha e os judeus convertidos. Exemplo disso é a maneira como judeus e cristãos-novos são apresentados nas obras de Gil Vicente. Nas peças de temática religiosa, encontramos os habituais - e insultuosos - estereótipos medievais. Nas peças profanas, contudo, os judeus são figuras populares autênticas, que fazem parte integrante da vida comunitária em escala local; mesmo quando representados de forma caricatural, os judeus de Gil Vicente são gente, pessoas reais (TEYSSIER, 1959, cap. 4). 
A persistência de tensões, bem como o exemplo da vizinha Espanha, vieram reforçar, em certos meios, uma corrente favorável à introdução da Inquisição. Mas as opiniōes encontravam-se divididas, e as políticas foram contraditórias. Em 1515, com o argumento de que um grande número de conversos oriundos de Espanha estava entrando clandestinamente no Reino, D. Manuel abordou o Papa no sentido de se estabelecer uma Inquisição em Portugal. Mas a proposta suscitou uma oposição considerável na Corte e acabou por ser abandonada.

Após a morte de D. Manuel, o seu sucessor, D. João III, reiterou as garantias dadas aos cristãos-novos - primeiramente, em 1522 e, de novo, em 1524. Mas, simultaneamente, cedendo à pressão crescente de alguns setores cortesãos, encetou negociações com Roma, utilizando como pretexto a agitação provocada entre os cristãos-novos pela pregação messiânica de David Reubeni (cf. SESTIERI, 1991). Em 1531, conseguiu obter do Papa uma bula que nomeava um Inquisidor para Portugal e retirava as questôes de fé da jurisdição episcopal, a qual, no entanto, foi revogada um ano mais tarde, sem mesmo ter sido publicada em Portugal. Foi só depois de outros cinco anos de negociações que D. João III obteve de Paulo III, apesar de todos os esforços financeiros e diplomáticos dos representantes dos cristãos-novos portugueses em Roma, a bula de estabelecimento de uma Inquisição, com três inquisidores nomeados pelo Papa e um pelo Rei. Ela foi publicada em Évora em 1536; o primeiro auto da fé foi celebrado em Lisboa em 1540 e, no ano seguinte, já tinham sido instalados tribunais em Lisboa, Évora, Coimbra, Porto, Tomar e Lamego. ${ }^{11}$

A aparente semelhança entre o que se passou nos dois reinos ibéricos e, em particular, a introdução em Portugal de uma Inquisição segundo o modelo espanhol, cuja preocupação principal era o "judaísmo" dos cristãos-novos, não nos deve fazer esquecer as diferenças entre uma situação e outra. Como já vimos, Portugal, ao contrário de Espanha, não teve que enfrentar um "problema converso" durante o século XV. Ao passo que no reino vizinho, onde tinham sido instituídos mecanismos de exclusão em algumas zonas desde meados do século XV, a Coroa portuguesa optou por encorajar, e mesmo impor, a integração dos cristãos-novos na sociedade católica. Na Espanha, a Inquisição fora instituída numa altura em que a prática do judaísmo ainda era permitida aos não católicos. Em Portugal, só foi introduzida quarenta anos depois da conversão forçada dos judeus e, durante esse intervalo, foi oficialmente permitido aos cristãos-novos que mantivessem em segredo, em suas casas, as práticas religiosas do judaísmo. Uma geração inteira foi educada num contexto de dualismo religioso e cultural: em público, tinham de se comportar como católicos; em privado, era-lhes permitido manter uma identidade própria judaica.

Por volta de 1530, as diferenças acentuaram-se. Na Espanha, aqueles conversos que ainda permaneciam no território tinham, em geral, se tornado católicos sinceros e praticantes; dos restantes, uns tinham abandonado o país e outros sido vitimados pelos tribunais inquisitoriais. ${ }^{12}$ Em Portugal, pelo contrário, a Inquisição ainda não existia, e uma proporção desconhecida, mas seguramente significativa, de cristãos-novos conservava uma identidade cultural e religiosa distinta do resto da população.

Não dispomos de qualquer indicação direta quanto à proporção de cristãos-novos na população portuguesa entre os séculos XVI e XVIII, ou quanto à proporção daqueles que se mantinham fiéis ao judaísmo. Mas existem dados que permitem uma estimativa indireta.

Não havendo casamentos mistos, e desde que não existisse emigração seletiva ou diferenças nas taxas de crescimento das duas sub-populações, a proporção de cristãos-novos na população total permaneceria constante. Havendo, pelo contrário, casamentos entre cristãos-novos e cristãos-velhos, a proporção de indivíduos de ascendência puramente judaica entre os cristãos-novos diminuiria de geração para geração, ao mesmo tempo que aumentaria aquela de ascendência judaica parcial. Uma vez que todos aqueles que contassem entre os seus ascendentes ao menos um judeu convertido eram considerados como cristãos-novos, os casamentos mistos também implicavam, necessariamente, um aumento, no conjunto da população, da proporção de indivíduos considerados como sendo de "sangue impuro" e, por isso mesmo, suspeitos na fé. 
Como vimos, no final do século XV, e na sequência da conversão forçada dos judeus, os cristãos-novos representavam cerca de $8 \%$ da população portuguesa. Nos centros urbanos, a proporção terá sido mais elevada, atingindo talvez $20 \%$ em algumas localidades. Imediatamente após a sua conversão, como também se viu, foram feitos esforços para obrigar os cristãos-novos a casar com cristãos-velhos, mas a lei, que ainda estava oficialmente em vigor no início do século XVI - há casos documentados de cristãos-novos que pediam autorização para poderem casar entre eles $^{13}$-, não parece ter tido aplicação generalizada.

Se admitirmos, a título de hipótese, que, em média, e em cada geração, 80\% dos cristãos-novos terão casado entre si, e $20 \%$ com cristãos-velhos, a sua proporção na população (contando como tais, de acordo com os critérios da época e da própria Inquisição, todos os descendentes de judeus convertidos no final do século XV) duplicaria cada quatro geraçóes, ou de 120 em 120 anos. Nesas condiçóes, os cristãos-novos, que constituiriam cerca de $8 \%$ da população em 1500 , representariam em torno de $17 \%$ da população em 1620 . Devido aos casamentos mistos, apenas $20 \%$ daqueles ainda seriam de ascendência judaica pura, $11 \%$ teriam - para utilizar as categorias da Inquisição - 1/8 ou 1/16 de cristãonovo, e os restantes $69 \%$ teriam entre $1 / 4$ e $1 / 2$ de cristão-novo.

Estes números, puramente hipotéticos e indicativos, podem ser confrontados com as informações fragmentárias fornecidas por algumas fontes da época. Em 1630, um grupo de 53 cristãos-novos apresentou-se perante a Inquisição de Lisboa. Confessaram que tinham permanecido fiéis ao judaísmo. ${ }^{14}$ Nesta ocasião, e excepcionalmente - talvez porque estas confissóes iriam constituir o ponto de partida para uma investigação mais ampla -, os Inquisidores tiveram o cuidado de anotar o estatuto genealógico preciso de cada indivíduo. Sete (13\%) foram descritos como cristãos-novos "inteiros"; oito (15\%) como "1/8 de cristão-novo"; e os restantes 38 (72\%) foram classificados, consoante os casos, como tendo 3/4, 1/2, 3/8, 1/4, ou simplesmente "parte" de cristão-novo.

Alguns anos mais tarde, um total de 96 cristãos-novos foram sentenciados por judaísmo no autoda-fé celebrado em Lisboa em 3 de agosto de 1636. Destes, não mais de vinte (21\%) eram cristãos-novos por inteiro; um era descrito como tendo $1 / 8$ de cristão-novo; e os restantes 75 (78\%) tinham 1/2, $1 / 4$ ou "parte" de cristão-novo. ${ }^{15}$

Se, por volta de 1630, entre os cristãos-novos de Lisboa acusados de judaísmo os de ascendência judaica pura representavam $20 \%$ ou menos, é muito improvável que, na mesma época, a proporção de cristãos-novos "inteiros" no conjunto dos cristãos-novos portugueses - incluindo nestes últimos aqueles que tinham perdido qualquer contato com o judaísmo - fosse maior. Assim sendo, e comparando estes números com os do nosso cálculo anterior, podemos inferir, à luz do modelo apresentado, que, em média, durante os primeiros 120 anos que se seguiram a 1497, pelo menos $20 \%$ dos casamentos de cristãos-novos terão sido mistos. A ter-se mantido esta taxa de exogamia durante as quatro gerações seguintes, podemos ainda concluir que, em 1740 , não menos de $34 \%$ da população portuguesa no seu conjunto, e provavelmente bem mais de metade da população das cidades e vilas, podia contar entre os seus ascendentes, mesmo que remotos, um ou mais dos judeus convertidos no final do século XV. Esta situação não era em nada comparável com a que se verificava na Espanha ou Itália - e o caráter particular da Inquisição portuguesa foi, pelo menos em parte, um reflexo desta especificidade.

Uma proporção esmagadora dos que foram sentenciados pela Inquisição portuguesa entre $1540 \mathrm{e}$ meados do século XVIII tinha sido acusada, como vimos, de "judaísmo". Com poucas exceções, as práticas que lhes eram imputadas, e que acabavam quase sempre por confessar, tinham sido descritas num documento impresso em 1536, na altura do estabelecimento da Inquisição em Portugal. Este documento, conhecido como Monitório do Inquisidor Geral, pretendia ser uma compilação dos sinais exteriores pelos quais se poderia reconhecer um criptojudeu. Mas em vez de descrever as práticas religiosas dos cristãos-novos portugueses uma geração após a sua conversão, o documento é, na realidade, uma 
mera reelaboração de textos produzidos pela Inquisição espanhola desde finais do século XV. ${ }^{16}$ Tal como é retratado no Monitório, o "judaísmo" dos cristãos-novos portugueses consistia nos seguintes ritos e observâncias: respeitar o Sábado, não trabalhando e vestindo roupa limpa ou joias nesse dia; limpar a casa e preparar comida para o dia seguinte às sextas-feiras; abater os animais à maneira judaica; não comer toucinho ou outros alimentos interditos; observar o Grande Jejum de Setembro, o da Rainha Esther e certos outros; celebrar a Páscoa dos judeus; realizar determinados ritos funerários; praticar a circuncisão; benzer os filhos sem fazer o sinal da cruz. Em termos mais gerais, numa evidente transposição de concepções religiosas católicas, os judaizantes eram acusados de "procurar a salvação de suas almas na Lei de Moisés". Embora houvesse casos em que o acusado confessava práticas e observâncias não incluídas no Monitório ou em textos semelhantes, a grande maioria consistia nos mesmos elementos estereotipados: o preso típico, cristão-novo, era acusado por vizinhos de "sentir mal" da fé católica, de não comer carne de porco e de vestir uma camisa lavada aos sábados; acabava por confessar estas práticas, juntamente com outras repetidamente citadas nos éditos da Inquisição e, finalmente, por fornecer uma lista de pessoas com as quais tinha feito declarações mútuas de fé na Lei de Moisés.

$\mathrm{Na}$ sua grande maioria, por conseguinte, os registros da Inquisição dão-nos pouquíssimas informações objetivas a respeito do judaísmo praticado pelos cristãos-novos portugueses. Tal como nos casos formalmente semelhantes dos processos de feitiçaria ou "luteranismo" durante a mesma época (ROWLAND, 1990; MENCHI, 1987), as acusaçôes refletem as convicções prévias dos Inquisidores tanto ou mais que os comportamentos ou as crenças reais dos acusados.

A Inquisição foi estabelecida em Portugal quase meio século após a conversão forçada de 1497, e quase todas as suas vítimas, mesmo durante os seus primeiros anos de atividade, foram formalmente educadas como católicas. Circunscrito à esfera doméstica, o seu judaísmo - que, a partir de 1536, se tornara uma potencial fonte de perigo - foi-se tornando progressivamente mais simplificado, e algumas práticas, como a circuncisão, tiveram de ser abandonadas. À medida que iam envelhecendo e morrendo os que ainda recordavam as velhas tradiçôes e ritos, começou a surgir um problema de transmissão cultural. Nos registros da Inquisição de Coimbra da segunda metade do século XVI, por exemplo, fala-se de jovens cristãos-novos que iam assistir aos autos da fé para memorizarem as orações reproduzidas nas sentenças dos condenados, porque nas vilas onde moravam já não havia ninguém que as conhecesse (MEÃ, 1981, p. 158).

Como sublinha este exemplo, o judaísmo dos cristãos-novos portugueses não era apenas uma tradição transmitida de geração em geração no espaço fechado das suas casas. Era também uma representação cultural que era projetada sobre eles, como que num espelho deformado, pela Inquisição e pelo resto da sociedade. Dadas as dificuldades de transmissão cultural clandestina, era inevitável que muitos cristãos-novos viessem a reconhecer-se nessa representação do judaísmo que lhes era imposta do exterior através das fórmulas estereotipadas das acusações ou dos rituais espetaculares da Inquisição.

\section{VI}

Segundo as regras do processo inquisitorial, alguém que persistisse em negar uma acusação de heresia que os Inquisidores davam como provada podia ser considerado negativo e, mesmo não sendo reincidente, condenado à fogueira. Isto porque a recusa de confessar indicava a falta de arrependimento, e só um herege arrependido podia ser reconciliado com a Igreja e readmitido à comunhão cristã. Do mesmo modo, alguém que fizesse uma confissão incompleta, omitindo, por exemplo, os nomes de um ou mais dos seus cúmplices, podia ser julgado diminuto e sofrer a mesma pena. Nestas circunstâncias, o acusado devia, no seu próprio interesse, fazer uma confissão plena e nomear todos aqueles que a Inquisição poderia considerar como seus cúmplices, porque assim porventura conseguiria, após uma confissão completa e satisfatória com os sinais apropriados de arrependimento e de uma abjuração pública dos seus erros, ser admitido à reconciliação, e, finalmente, depois de cumpridas as penitências que lhe fossem impostas, ser 
libertado. Apesar de nestas circunstâncias, como herege confesso, estar sujeito ao confisco dos seus bens, isto era obviamente preferível à sentença em que incorreria se fosse considerado negativo ou diminuto.

No caso de um cristão-novo que tivesse efetivamente mantido uma dupla existência religiosa - catolicismo em público, judaísmo em privado - a situação era clara. Se acusado e preso, podia optar entre fazer uma confissão completa, nomeando todos os que tivessem participado com ele em práticas judaicas, ou negar a acusação e correr o risco - caso a Inquisição julgasse suficientes as provas contra ele - de ser considerado diminuto ou negativo. Por outro lado, um cristão-novo que, por qualquer motivo, fosse injustamente acusado de judaísmo enfrentava o mesmo dilema, embora com outros contornos: podia optar entre negar a acusação, arriscando-se a ser condenado como negativo, ou inventar uma confissão falsa e uma lista plausível de cúmplices. Uma vez que o réu não tinha qualquer conhecimento nem das acusações que pendiam contra ele, nem dos nomes dos que o tinham acusado, esta era uma estratégia muito pouco segura. Se tivesse sido nomeado como cúmplice por outro cristão-novo - talvez tão inocente como ele próprio - mas não o tivesse incluído na sua própria lista de cúmplices, ou se tivesse omitido algum rito, cerimônia ou prática de que tivesse sido acusado, podia mesmo assim ser considerado diminuto.

Para se defenderem contra a perversidade do processo, alguns cristãos-novos elaboraram estratégias concertadas de proteção mútua. Aqueles que, por qualquer razão, temiam poder vir a ser presos - frequentemente um grupo de parentes - ajustavam entre si uma lista das práticas que deviam confessar e das pessoas que deviam nomear como cúmplices. Estes últimos, sabendo de antemão que iriam ser nomeados, podiam tentar antecipar-se à Inquisição e obter um tratamento mais favorável, apresentandose "espontaneamente" logo que soubessem que algum membro do grupo tinha sido preso e fazendo as confissões e denúncias conforme tinham combinado. Uma vez que as diferentes confissões e listas de cúmplices se confirmariam mutuamente, talvez a Inquisição as aceitasse como sinceras e completas.

Se acabassem por ser soltos, contudo, todos seriam tratados como hereges confessos e marginalizados. Podiam tentar recuperar o que restasse dos seus bens e procurar refúgio no estrangeiro, ou podiam permanecer em Portugal, contando com a solidariedade de suas redes de parentesco e da comunidade cristã-nova. Mas, em qualquer dos casos, mesmo que fossem inocentes, seriam definitivamente excluídos da convivência normal com cristãos-velhos e forçados a relacionarem-se predominante ou exclusivamente com cristãos-novos. Não deve surpreender que, nestas circunstâncias, mesmo aqueles cristãos-novos que haviam perdido quase todo o contato com a tradição original dos seus antepassados tivessem recuperado uma identidade judaica e aceitado com orgulho a imagem estereotipada que lhes tinha sido imposta pela Inquisição e pela sociedade dos cristãos-velhos, em alguns casos, chegando até a converter-se ao judaísmo em Amsterdã ou Londres. ${ }^{17}$ Era neste sentido que alguns cristãos-novos diziam que a Inquisição funcionava como uma "fábrica de judeus" (cf. SARAIVA, 1985, p. 121-126; BETHENCOURT, 1994, p. 297-301).

\section{VII}

Como afirmou I. S. Révah, não é em relação ao judaísmo ortodoxo que devemos analisar a religião dos cristãos-novos. Desprezados pelos cristãos-velhos, rejeitavam o catolicismo que os excluía; separados da tradição judaica e das comunidades de judeus de outros países, tentaram reconstruir uma identidade perdida a partir dos fragmentos que tinham à mão, muitos dos quais lhes chegavam filtrados e deformados pela Inquisição. O seu judaísmo era, para Révah, um judaísmo potencial, definido menos em termos de fé ou conhecimentos do que em termos de vontade. Seria precisamente esta vontade de serem judeus que explica o regresso ao judaísmo de muitos cristãos-novos que, nos séculos XVII e XVIII, deixaram Portugal e procuraram refúgio numa comunidade judaica no estrangeiro (RÉVAH, 1959-60). A sua definição da "religião dos marranos" como um "judaísmo da vontade" é, sem dúvida, correta, tal como a sua constatação de que esta vontade marrana de ser judeu era, em muitos casos, uma reação direta à injustiça arbitrária da perseguição inquisitorial e àquilo que denomina como o "racismo" das sociedades espanhola e portuguesa. Mas, apesar de ter reconhecido a contribuição da Inquisição na formação 
de uma representação do judaísmo que era partilhada por cristãos-velhos e cristãos-novos, Révah considerou o papel da Inquisição como adquirido e definiu o problema como sendo fundamentalmente o da transmissão, em condições adversas, de uma identidade religiosa e cultural dada de antemão.

Tal perspectiva essencialista não confere o peso devido às implicaçôes dos fatores demográficos já mencionados e, em particular, às consequências dos casamentos mistos entre cristãos-novos e cristãosvelhos. Como já vimos, a proporção observada de cristãos-novos “inteiros" entre acusados e condenados por judaísmo em Lisboa na primeira metade do século XVII implica que, em média, pelo menos $20 \%$ dos casamentos de cristãos-novos durante as quatro gerações após a conversão terão sido mistos. Este grau de permeabilidade entre as duas populações significa que a proporção da população portuguesa que era formalmente de "sangue impuro" e, por conseguinte, sujeita à discriminação, terá aumentado de 8\% em 1500 para cerca de 17\% em 1620 e - mantendo-se estável a taxa de exogamia ao longo das quatro geraçôes seguintes - para mais de 34\% em 1740. Nestas circunstâncias, era inevitável que a identidade cultural e religiosa judaica conservada por uma proporção muito significativa da primeira geração de conversos - os quais, como disse Samuel Usque, não mudaram "o segredo de [seus] corações” (1908, III, p. 32) - tivesse progressivamente se diluído, na medida em que os pais, por medo ou por opção, iam deixando de transmitir a tradição judaica aos seus filhos.

Mas, o processo não foi uniforme. Em alguns casos, podemos ter a certeza que alguns pormenores da observância religiosa judaica - incluindo o calendário - terão sido preservados e transmitidos até, pelo menos, as primeiras décadas do século XVIII. O caso de Antônio José da Silva, "o Judeu”, é emblemático. Quando, no dia 5 de outubro de 1737, os funcionários da Inquisição foram procurá-lo na sua casa em Lisboa, encontraram as mulheres da família sentadas no chão, vestidas de branco, celebrando o Yom Kippur. A Inquisição costumava referir-se ao Yom Kippur como "o Grande Jejum de Setembro", apesar de excepcionalmente - como em 1737 - poder ser celebrado em outubro, e não desconfiaram de nada. Não tendo conseguido localizar aquele que procuravam, foram-se embora. Quando, mais tarde, ele foi preso e condenado à morte, as acusaçôes contra ele não incluíam esta prova concludente do seu judaísmo, mas apenas os supostos jejuns judaicos que teria praticado no cárcere (RÉVAH e SARAIVA, 1985, p. 284-6; AZEVEDO, 1932, p. 143-218).

Em outros casos, podemos quase observar o processo de diluição e contaminação da tradição original. Em diversos processos quinhentistas, encontramos referências à Torá. Num processo de 1562, é descrita como um rolo de pergaminho que se mostrava àqueles que se costumavam reunir na casa do acusado e que, depois, era guardado. ${ }^{18} \mathrm{Já}$ em 1557 se falava de um quarto “onde adoram a toura” ${ }^{19}$ O emprego da forma vernácula toura abriu caminho a uma contaminação semântica. Em 1634, em Évora, uma menina de 12 anos confessou que sua mãe lhe tinha ensinado uma oração que devia ser recitada "ao boizinho de ouro" (COELHO, 1987, I, p. 363). Em 1609, na Covilhã, encontramos uma estatueta de uma "bezerrinha de prata", cuidadosamente conservada e transmitida de geração em geração por uma família de cristãos-novos (GARCIA, 1996, p. 70-71). No Nordeste brasileiro, em finais do século XVI, uma estatueta de barro em forma de vaca é descrita, numa denúncia perante o Visitador incrédulo, como sendo "a toura dos judeus" (GARCIA, 1929, p. 38). Um pouco mais tarde, ainda no Brasil, há referências a uma "Confraria da Toura", organizada e financiada por cristãos-novos (NOVINSKY, 1972, p. 159).

A transmissão da tradição cultural e religiosa judaica foi evidentemente seletiva. Em algumas linhas familiares continuaria viva, em outras extinguir-se-ia. É provável que, tal como entre os Xuetes de Maiorca, as alianças matrimoniais tenham sido utilizadas consciente e seletivamente para preservar um núcleo criptojudaico: alguns dos filhos casar-se-iam no interior do grupo, e a estes seria dada uma instrução religiosa; outros poderiam casar fora do grupo, com membros de famílias cristãs-novas não judaizantes ou com cristãos-velhos, e a estes tais ensinamentos "perigosos" não seriam ministrados (cf. PORQUERES, 1995).

Com tais formas de transmissão seletiva, a tradição podia a qualquer momento ser reativada, mesmo numa família onde havia sido extinta. Um indivíduo acusado injustamente de judaísmo, por exem- 
plo, e obrigado a fazer uma confissão falsa seria estigmatizado publicamente como cristão-novo e herege, sendo obrigado a procurar apoio junto de outros cristãos-novos. Progressivamente, poderia tentar recuperar a sua identidade judaica, buscando elementos junto de um ramo da sua ou de outras famílias, onde a tradição se conservava, ou simplesmente adotando a representação do judaísmo, dos seus ritos e cerimônias que lhe tinha sido veiculada pela Inquisição. Nesta situação, como observou Révah, a tradição era reativada pela repressão inquisitorial. Tais mecanismos terão sido tanto mais importantes e significativos quanto a tradição judaica se foi gradualmente diluindo de geração em geração no interior de uma população formalmente cristã-nova que, em consequência dos casamentos mistos, era cada vez mais numerosa - ao mesmo tempo que a Inquisição e a sociedade cristã-velha continuavam, com base na "limpeza de sangue", a discriminar todos os descendentes conhecidos de judeus convertidos, por tênue e remota que fosse a ligação genealógica e diluída a sua identidade judaica. Com o passar do tempo, a importância relativa da tradição herdada dos antepassados e da identidade estereotipada imposta do exterior ter-se-á alterado de forma dramática.

Por essas razões, é preciso examinar mais de perto, problematizando-os, os fatores subjacentes a dois dos elementos que Révah e outros autores consideraram como um dado adquirido: o contexto social onde continuaram a surgir acusações de judaísmo contra cristãos-novos e os mecanismos através dos quais a Inquisição garantia a sua própria sobrevivência.

\section{VIII}

Se a persistência de uma identidade judaica entre cristãos-novos pode ser explicada, em parte, pelo fato dela lhes ter sido constantemente transmitida e imposta pelos cristãos-velhos, e pela repressão a que eram sujeitos, como poderemos explicar a persistência da própria Inquisição? Tratou-se simplesmente de uma instituição que, para garantir a própria sobrevivência, precisava manter o seu ritmo de atividade e, por conseguinte, "fabricar" criptojudeus? Ou haverá outras razões que expliquem a sua longevidade?

Entre 1570 e 1770 , o número dos familiares ${ }^{20}$ da Inquisição portuguesa aumentou de maneira ininterrupta. Entre 1621 e 1670, em média, foram recrutados 46 familiares por ano; entre 1671 e 1720 , 110; e entre 1721 e 1770, 174. Durante o mesmo período, houve uma expansão análoga da burocracia inquisitorial: entre 1621-1670 e 1721-1770, o número de comissários aumentou de 297 para 1.011, e o número de qualificadores de 110 para 419. Mas esta expansão do aparelho burocrático não correspondia a qualquer necessidade funcional. Durante o mesmo período, o número de Deputados e Inquisidores manteve-se estável, aumentando de 117 para 119, ao mesmo tempo que o número de sentenciados passou de 11.154 para 3.895 (TORRES, 1994).

É evidente que a Inquisição estava sendo utilizada, em uma escala considerável, como instrumento de afirmação e ascensão sociais. A nomeação para qualquer cargo inquisitorial exigia uma investigação pormenorizada das genealogias do candidato e de sua mulher, de forma a determinar se havia vestígios de "sangue infecto". Com o passar do tempo, o fato de não haver numa família algum oficial ou familiar da Inquisição poderia levantar suspeitas quanto à pureza de sangue de todos os seus membros. Consequentemente, tanto o estatuto social dos indivíduos como o de suas famílias estava dependente do resultado dessas averiguações genealógicas. As vantagens de um cargo inquisitorial, tal como da pertença a uma das ordens militares, não decorriam apenas dos privilégios significativos que acarretavam, mas sobretudo do fato de nem todos poderem ter acesso a eles. ${ }^{21}$

Os familiares eram recrutados em todos os níveis da sociedade. Embora a proporção de artesãos tenha se reduzido após o final do século XVI, e a de mercadores tenha aumentado de maneira significativa durante o século XVIII, a sua composição social foi sempre variada. Por outro lado, apesar da importância numérica de cada grupo e, em particular, dos lavradores, ter sido muito diferente num caso e no outro, em geral a Inquisição recrutou os seus familiares entre os mesmos grupos sociais onde ia bus- 
car as suas vítimas. ${ }^{22}$ Em cada um destes grupos, o título de familiar terá acentuado a divisão entre cristãos-novos e cristãos-velhos, impedindo-a de desaparecer com o tempo.

A longa permanência desta distinção numa sociedade em que, por volta de 1740 , aqueles que, em princípio, podiam ser classificados como cristãos-novos representavam talvez um terço da população estava estruturalmente relacionada com a persistência da Inquisição e do seu papel na definição de estratégias de ascensão e de critérios de distinção e hierarquização sociais. Progressivamente, a "questão judaica” em Portugal tornou-se cada vez menos uma questão religiosa e cada vez mais uma questão de relação entre grupos sociais em todos os níveis da sociedade.

\section{IX}

Estas questões são, evidentemente, centrais para a nossa compreensão da sociedade portuguesa na época moderna e do papel desempenhado pela Inquisição. São também centrais para se perceber o sentido que se deve atribuir às acusações de criptojudaísmo dirigidas contra cristãos-novos em todos os níveis da hierarquia social. Menos óbvia, talvez, será a sua pertinência para a nossa percepção do papel desempenhado pelos cristãos-novos ibéricos na construção do Novo Mundo. Deve ser recordado, contudo, que os cristãos-novos portugueses não foram importantes só no Brasil colonial. Representavam, igualmente, uma proporção significativa dos mercadores conversos que desenvolviam as suas atividades nas possessões espanholas da América do Sul e Central. Por outro lado, os judeus que se transferiram de Amsterdã para Pernambuco, e daí para as Caraíbas e América do Norte, eram também, em grande parte, de origem portuguesa.

Como já vimos, a perseguição aos conversos espanhóis pela Inquisição estava mais ou menos terminada em meados do século XVI. Seguiu-se um período em que os inquisidores espanhóis se preocuparam mais com os delitos menores dos cristãos-velhos e, em Aragão, com os moriscos. Estes tribunais, e em particular os de Castela e da América espanhola, só retomaram a repressão do judaísmo quando, a partir de 1580, um elevado número de cristãos-novos portugueses dirigiu-se para a Espanha e para as possessóes espanholas. Uma proporção muito significativa dos processados por judaísmo pela Inquisição espanhola depois dessa data era, na realidade, portuguesa ou de origem portuguesa.

Isto significa que a experiência dos cristãos-novos portugueses e, em particular, os mecanismos subjacentes à transmissão e construção social da sua identidade religiosa e cultural são de importância decisiva para a nossa compreensão do papel desempenhado pelos cristãos-novos no conjunto das Américas. Ao contrário das vítimas da primeira fase da Inquisição espanhola, cuja identidade judaica raramente estava em questão, os cristãos-novos portugueses dos séculos XVII e XVIII eram o resultado final de um processo complexo em que as identidades católica e judaica se encontravam profundamente imbricadas. Como já foi sublinhado por diversos autores (cf. NOVINSKY, 1972; WACHTEL, 2001), a experiência interior dos cristãos-novos foi profundamente marcada pelo dualismo e pela ambiguidade. Examinar o seu papel na construção do Novo Mundo exclusivamente com base no seu componente judaico é contar apenas uma parte da história.

Tradução: Robert Rowland Revisão técnica: Maria Aparecida Rezende Mota 


\section{Notas}

${ }^{1}$ Este texto, inicialmente apresentado em 1997, num colóquio organizado pela John Carter Brown Library (Providence, R.I.) sobre o papel dos judeus na construção do Novo Mundo, destinava-se a equacionar e discutir alguns dos pressupostos subjacentes à organização do encontro e à estruturação do respectivo programa. Visava, em particular, chamar a atenção para aspectos que são, por vezes, elididos quando a experiência dos cristãos-novos ibéricos é abordada numa perspectiva de "história judaica", ou "Jewish history". No seu prefácio ao volume que resultou do colóquio, por exemplo, um dos organizadores, depois de referir que "os judeus estabeleceram-se em todo o hemisfério ocidental e participaram (muitas vezes como conversos) nos impérios espanhol, português, francês, holandês e inglês", justificou a inclusão, num estudo sobre "os judeus nas Américas durante a época moderna”, dos "milhares de cristãos descendentes de judeus [...]”, com o argumento de que estes, "apesar da sua conversão, por mais remota no tempo que esta tivesse sido, e independentemente das suas práticas efetivas, continuavam a ser geralmente considerados como “judeus”' (FIERING, 2001, p. xi, xiii).

${ }^{2}$ Os judeus convertidos e seus descendentes eram geralmente designados por conversos em Espanha e cristãos-novos em Portugal. Os dois termos podiam, também, ser utilizados para designar os muçulmanos convertidos, pelo que em Espanha se utilizava, por vezes, a expressão mais precisa de cristiano nuevo de judío. Utilizo aqui o termo genérico cristão-novo para designar os judeus convertidos e seus descendentes em ambos os reinos ibéricos. Na esteira de I. S. Révah (1959-60), reservo o termo marrano para aqueles cristãos-novos que, efetivamente, se esforçaram por conservar, ainda que imperfeitamente, uma forma de identidade própria através da manutenção de algumas práticas judaicas.

${ }^{3}$ Que fosse considerado como tal, ou não, pelas comunidades e autoridades religiosas judaicas fora da Península Ibérica é uma questão diferente, que não posso abordar aqui. Sobre as discussões havidas no seio dessas comunidades a respeito do judaísmo dos cristãos-novos ibéricos, ver, em particular, Yerushalmi 1971, cap. 1.

${ }^{4}$ Apesar das ressonâncias atuais de termos como "limpeza de sangue", noções como as de antissemitismo e racismo - que se referem a fenômenos historicamente específicos e mais recentes - são anacrônicas e não têm cabimento no contexto da Espanha e de Portugal na época moderna.

${ }^{5}$ Estes resultados, fruto das pesquisas de E.W. Monter, J. Tedeschi, J. P. Dedieu, J. Demonet, G. Henningsen, J. Contreras, J. Veiga Torres e A. Borges Coelho - foram utilmente sintetizados, numa perspectiva comparativa, por Bethencourt, 1994, p. $268-284$.

${ }^{6}$ O Secretariado de Aragão compreendia os tribunais de Barcelona, Logroño, Maiorca, Sardenha, Sicília, Valência, Saragoça, Cartagena das Índias, Lima e México; o de Castela, os tribunais das Ilhas Canárias, Córdova, Galiza, Granada, Llerena, Múrcia, Sevilha, Toledo e Valhadolid.

${ }^{7}$ Cf. Tavares 1982, I, p. 74. Segundo as estimativas anteriores de João Lúcio de Azevedo (1921, p. 43), a população judia em finais do século XV poderia ascender a 75.000. Tal número traduz-se, no entanto, numa proporção extraordinariamente elevada de judeus entre a população urbana - da qual não há menção nas fontes qualitativas da época -, devendo, por conseguinte, ser considerada como excessiva.

${ }^{8}$ Estas medidas baseavam-se na bula Sicut iudaeis non, de 2 de julho de 1389, do Papa Bonifácio IX, a qual D. João I mandou publicar em Portugal em 17 de julho do mesmo ano. Segundo as Ordenaçôes Afonsinas (II, p. 120), compiladas em meados do século XV, nenhum cristão tinha o direito de matar ou ferir um judeu, furtar os seus bens, ou ofender os seus costumes. Tampouco tinha o direito de violar os seus cemitérios (com o pretexto da procura de tesouros), de perturbar as suas festas, ou de obrigar qualquer judeu a servi-lo ou a desempenhar trabalhos forçados (KAYSERLING, 1971, p. 39).

${ }^{9}$ Segundo a estimativa mais recente de Maria José Ferro Tavares, o número de refugiados não terá ultrapassado os vinte ou trinta mil. Entre os contemporâneos, contudo, Abraão Zacuto fala de 120.000 indivíduos, Damião de Góis de 20.000 famílias. O cronista espanhol Bernáldez afirma que 93.000 judeus terão ultrapassado a fronteira. Estes números têm sido, por vezes, reproduzidos sem reservas por historiadores modernos, mas isto implicaria que, no espaço de poucos anos, a proporção de judeus em Portugal tivesse passado de 3-4\% para $15 \%$ da população total e, em muitos centros urbanos, talvez de $8 \%$ para mais de $30 \%$ da população. Como isto, evidentemente, não foi o caso, tais estimativas têm necessariamente que ser consideradas exageradas. Cf. Tavares 1982: I, 252-257, e Azevedo 1921: 20-22.

${ }^{10}$ Várias centenas de cristãos-novos perderam a sua vida no massacre de Lisboa. Segundo Damião de Góis e Samuel Usque, o número de vítimas teria sido, respectivamente, de 1.900 e 4.000, mas isto constitui provavelmente um exagero. Cinquenta dos que foram considerados responsáveis pelo massacre acabaram por ser condenados à morte. A população de Lisboa perdeu alguns dos seus privilégios e a cidade foi sujeita a uma multa pesada.

${ }^{11}$ Os três últimos tribunais tiveram, no entanto, uma existência muito curta. Mais tarde, em 1558, foi criado um quarto tribunal em Goa, com jurisdição sobre a África Oriental e todo o Oriente. Sobre o estabelecimento da Inquisição em Portugal, veja-se o estudo clássico de Alexandre Herculano (1854-59).

${ }^{12}$ Sobreviviam, ainda, algumas comunidades isoladas, que a Inquisição veio a descobrir e a dispersar ao longo das décadas seguintes. Para uma visão de conjunto, cf. Contreras, 1993.

${ }^{13}$ Cf. Biblioteca Nacional de Lisboa (BNL), Reservados, Cod. 863, fol. 1. 
${ }^{14}$ A lista está reproduzida em ibid., fols. 97-98. Sem uma análise dos processos individuais, não é possível saber em que medida este grupo era representativo do conjunto da população cristã-nova de Lisboa. Mas o fato de terem confessado espontaneamente, temendo, talvez, ser denunciados por outros (cf. adiante, seção VI), sugere que poderão, no mínimo, ser considerados como representativos do tipo de cristão-novo que, 133 anos após a conversão forçada, poderia ainda, com alguma plausibilidade, ser acusado de judaizar.

${ }^{15}$ Ibid., fols 119-123. Surpreendentemente, quando chegamos ao século XVIII, a grande maioria dos acusados de judaísmo é descrita apenas como "cristã-nova": 94\% dos sentenciados no auto da fé celebrado em Lisboa a 19 de outubro de 1704, ou 85\% no de 25 de julho de 1728 (ibid., fols. 353-6, 437-9). Embora seja possível que, tal como em Maiorca, estratégias matrimoniais seletivas por parte de algumas famílias possam ter levado à constituição de um grupo endógamo judaizante no interior da população cristã-nova (cf. PORQUERES, 1995), parece mais provável que a esta data, tardia, as sutilezas genealógicas já tivessem sido abandonadas e que o termo genérico "cristão-novo" fosse aplicado indiscriminadamente a todos os de ascendência judaica conhecida. Cf., no entanto, Révah (1959-60, p. 50), que interpreta estes números como uma indicação de que, mesmo no século XVIII, “o cripto-judaísmo português mantivera uma surpreendente homogeneidade racial”.

${ }^{16} \mathrm{O}$ conteúdo deste documento foi analisado em pormenor por H. P. Salomon (1982), o qual também reproduz, em facsímile, o texto original impresso.

${ }^{17}$ Esta estratégia foi descrita em pormenor num manuscrito redigido, por volta de 1735, pelo conhecido médico cristão-novo Ribeiro Sanches (SANCHES, 1973), o qual, tendo sido educado no catolicismo, veio a ser injustamente denunciado à Inquisição por um seu primo como judaizante. Acabou por fugir para Londres, onde se converteu ao judaísmo, mas posteriormente regressou à fé católica, tendo-se ainda tornado médico de Catarina da Rússia. Sobre a reinvenção de identidades e tradiçôes judaicas, cf. também Bodian, 1997.

${ }^{18}$ Arquivo Nacional da Torre do Tombo (ANTT), Inquisição de Lisboa, Processo No 1266.

${ }^{19}$ Ibid., Processo No 236.

${ }^{20}$ Os familiares eram colaboradores leigos da Inquisição que, como tal, deviam fazer prova de "limpeza de sangue". Entre outras funções, eram encarregados, mais especificamente, de executar a prisão dos suspeitos e acusados.

${ }^{21}$ Cf. o excelente estudo de Fernanda Olival (1997) sobre as tentativas de acesso à Ordem de Cristo por parte de uma família de remota ascendência cristã-nova.

${ }^{22}$ As informações de que dispomos não permitem uma comparação estatística rigorosa. Cf., no entanto, os números apresentados por Borges Coelho (1987, I, p. 383) e por Veiga Torres (1994, p. 133). Dos 5.382 indivíduos processados pela Inquisição de Évora entre 1537 e 1668, 22\% eram mercadores ou comerciantes, 42\% artesãos, 9\% lavradores e 4\% trabalhadores. Durante o mesmo período, os lavradores representavam quase metade dos familiares, enquanto que os artesãos, mercadores e fidalgos perfaziam, respectivamente, $15 \%, 13 \%$ e $6 \%$ do número total. Entre 1721 e 1770, a proporção de lavradores tinha diminuído para $28 \%$, representando os outros três grupos, respectivamente, $6 \%$, $37 \%$ e $5 \%$.

\section{Referências bibliográficas}

AZEVEDO, João Lúcio. História dos cristãos-novos portugueses. Lisboa, 1921. . Novas Epanáforas. Lisboa, 1932.

BERNARDINI, Paolo and FIERING, Norman. The jews and the expansion of Europe to the west, 1450-1800. New York and Oxford, 2001.

BETHENCOURT, Francisco. História das Inquisiçôes. Portugal, Espanha e Itália. Lisboa, 1994.

BODIAN, Miriam. Hebrews of the portuguese nation: Conversos and community in early modern Amsterdam. Bloomington, 1997.

CARENA, Cesare. Tractatus de Officio Sanctissimae Inquisitionis et modo procedendi in casus fidei. Cremona, 1655. COELHO, António Borges. A Inquisiz̧ão de Évora. Lisboa, 1987.

CONTRERAS, Jaime \& HENNINGSEN, Gustav. Forty-four thousand cases of the Spanish Inquisition (15401700): analysis of a historical data bank. In: HENNINGSEN, G. \& TEDESCHI, J. (Eds.). The Inquisition in early modern Europe. Studies on sources and methods. Illinois,1986, p. 100-130.

CONTRERAS, Jaime. Estructura de la actividad procesal del Santo Oficio. In: VILLANUEVA, J. Pérez \& BO-

NET, B. Escandell (Dir.). Historia de la Inquisición en España y América. Madrid, 1993. II, p. 621-7.

DEDIEU, Jean-Pierre. L'administration de la foi. L'Inquisition de Tolède, XVI - XVIII siècle. Madrid, 1989.

DOMÍNGUEZ ORTIZ, Antonio. Los judeoconversos en España y América. Madrid, 1988. 
EYMERICUS, Nicolaus. Directorium Inquisitorum. Roma, 1578.

FIERING, Norman. Preface. In: BERNARDINI \& FIERING. 2001, p. xi-xv.

GARCIA, Maria Antonieta (Ed.). Denúncias em nome da fé. Perseguiçāo aos judeus no Distrito da Guarda de 1607 a 1625. Lisboa, 1996.

GARCIA, Rodolfo (Ed.). Primeira visitação do Santo Oficio às partes do Brasil pelo Licenciado Heitor Furtado de Mendonça. Denunciações de Pernambuco, 1593-1595. São Paulo, 1929.

GÓIS, Damiāo de. Crónica do Felicíssimo D. Manuel. Coimbra [1566-7], 1949.

HERCULANO, Alexandre. História da origem e estabelecimento da Inquisição em Portugal. Lisboa, 1854-59.

KAYSERLING, M. História dos judeus em Portugal. São Paulo, 1971.

[MASINI, Eliseo] Sacro Arsenale, ovvero prattica dell"officio della S. Inquisitione. Genova, 1625.

MEA, Elvira Cunha de Azevedo. Oraçōes judaicas na Inquisição portuguesa - século XVI. In: KAPLAN, Y. (Ed.). Jews and conversos. Studies in society and the Inquisition. Jerusalem, 1981.

MENCHI, Silvana Seidel. Erasmo in Itália. Torino, 1987.

NOVINSKY, Anita. Cristãos-Novos na Bahia. São Paulo, 1972.

OLIVAL, Fernanda. O acesso de uma família de cristãos-novos portugueses à Ordem de Cristo. Ler História 33, 1997, p. 67-82.

PORQUERES, Enric. Lourde Alliance: mariage et identité chez les descendants de juifs convertis à Majorque (14351750). Paris, 1995.

RÉVAH, Israel S. Les Marranes. Revue des Etudes Juives CXVIII/1. 1959-60, p. 29-77.

RÉVAH, Israel S. \& SARAIVA, A. J. Polémica acerca de "Inquisição e cristãos-novos" entre I. S. Révah e António José Saraiva. In: SARAIVA, A. J. Inquisiçāa e cristāos-novos. 5a ed. Lisboa, 1985, p. 211-291.

ROWLAND, Robert. Fantasticall and Devilishe Persons: European Witchcraft in Comparative Perspective. In: ANKARLOO, B. \& Henningsen, G. (Eds.). Early modern European witchcraft. Centres and peripheries. Oxford, 1990, p. 161-190.

SALOMON, H. P. The "Monitório do Inquisidor Geral" of 1536. Background and sources of some "judaic" customs listed therein. Arquivos do Centro Cultural Português XVII. 1982, p. 41-64.

SANCHES, A. N. Ribeiro. Christãos-novos e christãos-velhos em Portugal (ed. Raul Rego). Porto, 1973.

SARAIVA, António José. Inquisição e cristãos-novos. 5ạ ed. Lisboa [1969], 1985.

SESTIERI, Lea. David Rubeni. Un ebreo d'Arabia in missione segreta nell'Europa del '500. Genova, 1991.

STOW, Kenneth R. Ebrei e inquisitori. In: LUZZATI, M. (Ed.). L'Inquisizione e gli ebrei in Itália. Rome e Bari, 1994, p. 3-18.

TAVARES, Maria José Pimenta Ferro. Os judeus em Portugal no século XV. Lisboa, 1982. . Judaísmo e Inquisição, Lisboa, 1987.

TEYSSIER, Paul. La langue de Gil Vicente, Paris, 1959.

TORRES, José Veiga. Da Repressão Religiosa para a Promoção Social. A Inquisição como instância legitimadora da promoção social da burguesia mercantil. Revista Crítica de Ciências Sociais 40, 1994, p. 109-135.

USQUE, Samuel. Consolaçam às tribulaçoens de Israel, Coimbra [1553], 1908.

WACHTEL, Nathan. Marrano Religiosity in Hispanic America in the Seventeenth Century. In: BERNARDINI \& FIERING, 2001, p. 149-171.

YERUSHALMI, Yosef H. From Spanish court to Italian ghetto. Isaac Cardoso: A Study in seventeenth-century marranism and jewish apologetics. New York and London, 1971. 
Robert Rowland

\title{
RESUMO
}

No mundo ibérico dos séculos XVI, XVII e XVIII todos os judeus remanescentes eram necessariamente clandestinos, o que implicava a necessidade de dissimular suas práticas e seus sentimentos religiosos. Na medida em que aquilo que sabemos a seu respeito resume-se, quase exclusivamente, às informaçōes produzidas pela Inquisição, podemos ter a certe$z a$ de que nem todas tinham uma base factual. Não dispomos, entretanto, de critérios claros e objetivos que permitam determinar quais confissöes e acusaçōes eram verdadeiras. Portanto, como veremos neste ensaio, entender por que determinado individuo era considerado judeu passa por um exame contextual mais aprofundado da situação dos cristãosnovos na sociedade ibérica, do papel da Inquisição em diferentes lugares e épocas, e, por fim, das circunstâncias específicas de cada acusação individual.

Palavras-chave: cristãos-novos, marranos, judeus, sociedade ibérica, Inquisição.

\begin{abstract}
The only Jews who remained in the Iberian world were, of necessity, clandestine Jews, concerned with dissimulating their religious sentiments and practices. The Judaism of Iberian New Christians, as recounted in Inquisitorial records, cannot thus be taken at its face value. So, we can also be sure that not every confession to having practiced Judaism in secret, and not every accusation made during interrogation, had a factual basis. As we do not possess unambiguous criteria for deciding which accusations and confessions were true, the clarification of the issue - as we shall see in this essay - can only be provided by closer attention to context: to the changing situation of New Christians in Iberian society, to the role played by the Inquisition at a given time and place, and to the circumstances surrounding individual acts of accusation. Keywords: New Christians, Marranos, Jews, Iberian society, Inquisition.
\end{abstract}

